\title{
Physical Vulnerability of Coastal Zone of Sidoarjo Distric to Potential Impact of Sea Level Rise due to Climate Change
}

\author{
Hermawan Kurnianto ${ }^{1}$, Mohammad Bisri ${ }^{2}$, Maftuch ${ }^{3}$ \\ ${ }^{1}$ Post Graduate School of Environmental and Development, Graduate, Program, Brawijaya University \\ ${ }^{2}$ Department of Water Resources Engineering, Faculty of Engineering, Brawijaya University \\ ${ }^{3}$ Department of Aquaculture, Faculty of Fisheries and Marine Science, Brawijaya University
}

\section{Abstract}

Climate change impact such as an increased on the intensity and the frequency of rainfall in the oceans cause sea level rise which then impacts the water surface in the river. This condition has an impact on fishery cultivation in coastal areas. People in Sidoarjo regency are increasingly affected by the alteration of water surface in coastal areas. Sidoarjo region is divided into 5 sub-development areas of one of the 5 sub-regional development units (SSWP V) which are a coastal area with aquaculture fisheries aquaculture economic center. Physical parameter indicators including secondary data and spatial map (GIS) were conducted. The result showed that 4 villages with the highest physical vulnerability of Sidoarjo Regency to the impact of climate change including Kalanganyar Village, Kupang, Tambak Kalisogo and Permisan.

Keywords: Coastal, Exposure, GIS, Sea level rise

\section{INTRODUCTION}

Climate change resulted in sea level rise globally in the world, as well as the increased intensity and frequency of storms in the sea and coastal areas. The negative impacts of climate change include the inundation of coastal areas and the threat of sinking of the smallest islands due to rising sea levels, tropical storms, waves and coastal flood [1]. Global and regional assesments have been initiated to determine the vulnerability of country to various impacts of climate change Cities in Indonesia have a wide range of geographical characteristics nature of this country that includes mountains to coastal and archipelago [2]. Of the 94 autonomous cities in Indonesia, 47 of them have coastal areas.

Of the 47 coastal cities in Indonesia, there are 32 cities prone to flooding, there are 29 cities prone to tsunamis, and there are 15 cities prone to tidal waves [3]. Referring to the East Java provincial government regulation, Sidoarjo regency seeks to improve the planning process to protect and control and improve the welfare of society by issuing Local Government Regulation of Sidoarjo Distric No. 5 in 2011 about Protection and Supervision of Coastal Area and Small Island. In the regulation of the Government of Sidoarjo

\footnotetext{
Correspondence address:

Hermawan Meidy Kurnianto

Email : hermawankurnianto@gmail.com

Address : Post Graduate School of Environmental and Developmen, Graduate Program, Brawijaya University, Malang, Indonesia
}

Regency it is explained that coastal waters are sea bordering land covering waters as far as four nautical miles measured from coastline, waters connecting coast and islands, estuary, bay, shallow waters, swampy and lagoon [5].

Sidoarjo Distric in 2010 was in 133 which included in the high disaster vulnerable city [3], while in 2013 it was in 298 cities vulnerable to disaster which is still classified as high category [4], the government of Sidoarjo Distric attempts to reduce its risk index up to $30 \%$ in every year [4]. Where it is the center of "SSWP V" zoning in accordance with the spatial plan plan of Sidoarjo Distric where coastal development dominates the livelihood of the people are fishponds [8], and disasters the threat is the coastal flood [6].

The purpose of this research is to know the vulnerable villages in the coastal area of Sidoarjo regency using AHP methode and spatial map (GIS) through secondary data processing.

\section{MATERIAL AND METHOD}

Quantitative method is used in this research analyze, Data collect from relevant agency/OPD and focus research analyzes on the physical vulnerability of coastal areas that are inundated with "SSWP V" area and coastal area boundary coastal that is four kilometers from beach in Sidoarjo [5]. Final identification there are have 8 sub-district consists of 20 villages.

The analyses of method processing data from each village to compared with total area/district, so as to get range of values between minimum (1) until maximum (5) [7], where each is 
determined its weight to then be displayed by spatial map so it can be known clearly which areas are not vulnerable, vulnerable and are highly vulnerable to physical parameters from indicators of land area, historical floods, elevation, rainfall, mangrove area, early warning system, pond area near to the river and water supply system from the study area.

\section{Data Collection}

Methods of data collection in this study analyze using secondary data where data obtained from several agencies in Sidoarjo Distric such as Regional Planning and Development Agencies, Regional Disaster Management Agency, Fisheries Agency and several other agencies involved. The data obtained with the village scale. Data acquisition by institution is as follows:

Table 1. Data Research and Proceesing

\begin{tabular}{|c|c|c|}
\hline No & Data & Data Obtained \\
\hline 1 & Villages land area & $\begin{array}{l}\text { Village middle term of } \\
\text { development plans }\end{array}$ \\
\hline 2 & Historical disaster & RPB BPBD \\
\hline 3 & Rainfall & $\begin{array}{l}\text { Village middle term of } \\
\text { development plans }\end{array}$ \\
\hline 4 & Mangrove area & Google Earth analyze \\
\hline 5 & Fishpond area & Subdistric data \\
\hline 6 & $\begin{array}{l}\text { Fishpond area near } \\
\text { from the river supply }\end{array}$ & Google Earth analyze \\
\hline 7 & Water supply fishpond & $\begin{array}{l}\text { Village middle term of } \\
\text { development plans }\end{array}$ \\
\hline
\end{tabular}

Source: Secondary data obtained

\section{RESULT AND DISCUSSION}

Vulnerability is the probable level of an object of disaster consisting of society, service structure or geographical area suffered damage or disruption due to impact of disaster. Although definitions can vary, vulnerability is generally considered to be the degree to which a system is susceptible to, and unable to cope from disaster [10].

Some of the vulnerable builders include; the number of people, the place where a group is in a vulnerable position and the possessed assets of a territory. In this vulnerability study calculates the physical vulnerability (the place where a group is in a vulnerable position).

Physical vulnerability is a vulnerability indicator that is measured based on material condition, criteria of area and infrastructure including vulnerability in the event of coastal flood disaster.

Referring to Regional Regulation of East Java Province No. 6 of 2012 about Management and plan of zoning of coastal area and Small Island in year 2012 to 2032. Province coastal boundary is as far as 12 nautical miles in measuring from shoreline and coastal waters is sea bordering with mainland covering 12 miles connecting estuaries, bays, shallow waters, swamps and lagoons. But the district is entitled to manage the territory's resources within the 4 mile border of the shoreline [9].

Thus, based on the identification of the 4 mile area by using GIS application from Google Earth analyze, 26 exposed villages were used as the first basis for identifying vulnerability assessment sites. The coastal villages are shown in the figure 1.

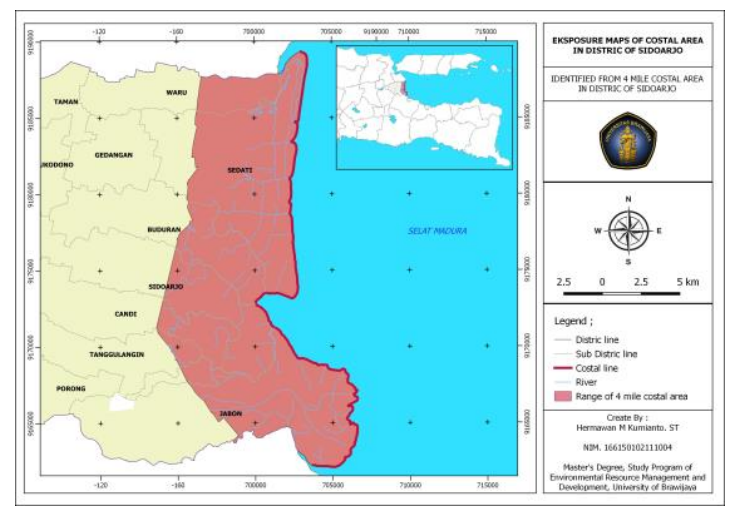

Figure 1. The Proportion of 4 Mile Coastal Area for Fishery

Meanwhile, based on the zoning plan of coastal areas and small islands contained in the Regional Regulation of Sidoarjo Distric No. 5 of 2011 on the Protection and supervision of Coastal Zone and Small Island into coastal areas. SSWP V area obtained a number of 22 villages, while the village location is shown in the figure 2.

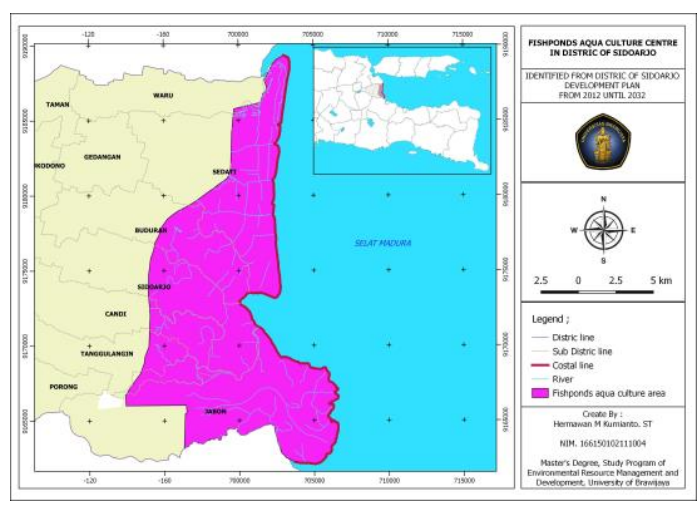

Figure 2. The Proportion of SSWP $\mathrm{V}$ area according to spatial plan of Sidoarjo Distric.

The result of coastal area overlay with 4 mile boundary of coastline with SSWP $V$ area map in 
Sidoarjo Regency using GIS application obtained by 18 study area villages that will be analyzed based on the physical vulnerability of the area. The villages analyzed are shown in the figure 3.

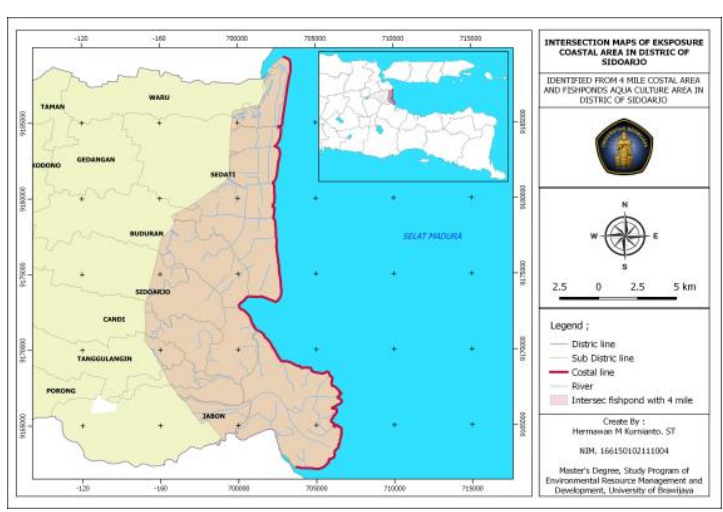

Figure 3. The Results of Intersection Coastal Areas of Fisheries with SSWP V in Sidoarjo.
Determination of vulnerability level of each unit analysis classifying the weights obtained in accordance with the clustering and then spatially overlaying the whole map to show the areas along the coast of the coastal vulnerability indexes in the high, medium and low category [15].

The result of physical vulnerability analysis in the above table is then incorporated into the GIS application format, so that it can be considered as a region / village that is vulnerable to the impact of the flood due to climate change in Sidoarjo distric. With the legend of green color for the area is not vulnerable to the red color for areas that are very vulnerable to disaster.

In the vulnerability map below it can be seen that the most vulnerable areas are Kalanganyar, Kupang, Tambak Kalisogo and Permisan villages. Based on the number of village locations analyzed, the input data acquisition is table 2 .

Table 2. Data Proceesing and Result

\begin{tabular}{|c|c|c|c|c|c|c|c|c|c|}
\hline \multirow[b]{3}{*}{ Villages } & \multicolumn{9}{|c|}{ Physicaly Category } \\
\hline & Area & $\begin{array}{l}\text { Disaster } \\
\text { history }\end{array}$ & Elevation & Rainfall & $\begin{array}{c}\text { Mangrove } \\
\text { area }\end{array}$ & $\begin{array}{c}\text { Early } \\
\text { warning } \\
\text { system }\end{array}$ & $\begin{array}{c}\text { Fishpond } \\
\text { area }\end{array}$ & $\begin{array}{c}\text { Fishpond } \\
\text { near the } \\
\text { river }\end{array}$ & Water supply \\
\hline & $\begin{array}{l}\text { village } \\
\text { area/sidoa } \\
\text { rjo area }\end{array}$ & $\begin{array}{l}\text { historical } \\
\text { disaster in } \\
\text { village/all } \\
\text { histrorical }\end{array}$ & $\begin{array}{c}0-3 ; \\
\text { upstream, } \\
3-10 ; \\
\text { middle, } \\
10-25 ; \\
\text { downstrea } \\
\text { m } \\
\end{array}$ & $\begin{array}{c}\text { Rainfall in } \\
\text { village/sid } \\
\text { oarjo } \\
\text { rainfall }\end{array}$ & $\begin{array}{l}\text { mangrove in } \\
\text { village/all } \\
\text { mangrove } \\
\text { identified }\end{array}$ & $\begin{array}{l}\text { EWS in } \\
\text { village/al } \\
\text { I EWS in } \\
\text { sidoarjo }\end{array}$ & $\begin{array}{c}\text { fishpond in } \\
\text { village/fish } \\
\text { pond in } \\
\text { area } \\
\text { analyze }\end{array}$ & $\begin{array}{l}\text { fishpond } \\
\text { near the } \\
\text { river in } \\
\text { village/all } \\
\text { fishpond }\end{array}$ & $\begin{array}{c}1=\text { water botlle } \\
2=\text { PDAM } \\
3=\text { water pump } \\
4=\text { water spring } \\
5=\text { rainfall, river }\end{array}$ \\
\hline Gebang & 0.122 & - & 4.000 & - & 0.054 & - & 0.103 & 0.433 & 5.000 \\
\hline Pucanganom & 0.027 & - & 4.000 & - & - & - & 0.028 & 0.331 & 5.000 \\
\hline Prasung & 0.035 & - & 4.000 & 0.039 & - & - & 0.022 & 0.102 & 5.000 \\
\hline Sawohan & 0.080 & - & 4.000 & 0.039 & 0.018 & - & 0.061 & 0.653 & 2.000 \\
\hline Damarsi & 0.022 & - & 4.000 & 0.039 & - & - & 0.015 & 0.210 & 5.000 \\
\hline Pepe & 0.021 & - & 4.000 & 0.037 & - & - & 0.024 & 0.044 & 5.000 \\
\hline Kalanganyar & 0.138 & 5.000 & 4.000 & 0.037 & 0.198 & - & 0.144 & 0.401 & 5.000 \\
\hline Tambak cemandi & 0.034 & - & 4.000 & 0.037 & 0.075 & - & 0.030 & 0.656 & 5.000 \\
\hline Segoro tambak & 0.054 & 5.000 & 4.000 & 0.037 & 0.061 & - & 0.035 & 0.928 & 2.000 \\
\hline Banjar kemuning & 0.025 & - & 4.000 & 0.037 & 0.020 & - & 0.028 & 0.314 & 2.000 \\
\hline Tambakoso & 0.028 & - & 5.000 & - & - & - & 0.005 & 0.420 & 1.000 \\
\hline Kedung peluk & 0.060 & - & 4.000 & 0.103 & 0.016 & - & 0.067 & 0.359 & 5.000 \\
\hline Plumbon & 0.028 & - & 4.000 & 0.082 & 0.010 & - & 0.029 & 0.329 & 5.000 \\
\hline Kupang & 0.179 & 5.000 & 2.000 & 0.030 & 0.493 & - & 0.068 & 1.203 & 5.000 \\
\hline Tambak kalisogo & 0.074 & 5.000 & 2.000 & 0.030 & 0.044 & - & 0.055 & 0.429 & 5.000 \\
\hline Permisan & 0.042 & 5.000 & 2.000 & 0.030 & 0.009 & - & 0.057 & 0.177 & 5.000 \\
\hline Banjarasri & 0.011 & - & 4.000 & - & - & - & 0.006 & 0.168 & 5.000 \\
\hline Banjarpanji & 0.020 & - & 4.000 & - & - & - & 0.022 & 0.237 & 5.000 \\
\hline
\end{tabular}

Source: Secondary data obtained $[11,12,13,14]$ 
Based on the number of village locations analyzed, as well as secondary data input, the value obtained for weighting as the basis for determining the vulnerability of coastal areas in the table 3.

Table 3. Data Proceesing and Result

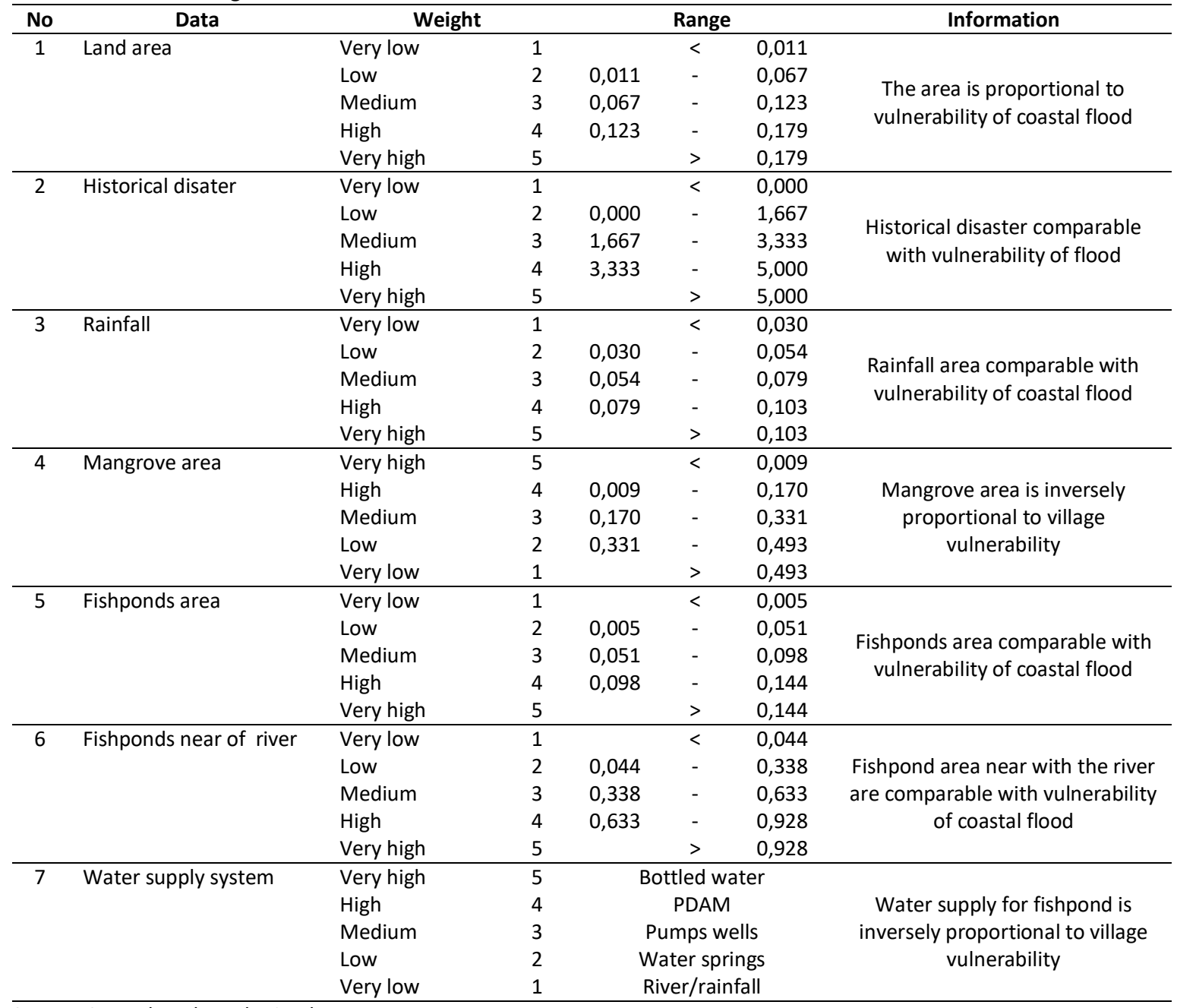

Source: Secondary data obtained

Based on the range of weight determined, then obtained a weight for each of indicators of the parameters of physical vulnerability in table 4 .

Table 4. Result of the Model

\begin{tabular}{|c|c|c|c|c|c|c|c|c|c|c|c|}
\hline Villages & Area & $\begin{array}{l}\text { Disaster } \\
\text { history }\end{array}$ & Elev. & Rainfall & $\begin{array}{c}\text { Mangrove } \\
\text { area }\end{array}$ & EWS & $\begin{array}{c}\text { Fishpond } \\
\text { area }\end{array}$ & $\begin{array}{l}\text { Fishpond } \\
\text { near the } \\
\text { river }\end{array}$ & $\begin{array}{l}\text { Water } \\
\text { supply }\end{array}$ & Tot & $\begin{array}{l}\text { Average } \\
\text { (Total/9) }\end{array}$ \\
\hline Gebang & 3 & 1 & 3 & 1 & 4 & 5 & 4 & 3 & 1 & 25 & 2.8 \\
\hline Pucanganom & 2 & 1 & 3 & 1 & 0 & 5 & 2 & 2 & 1 & 17 & 1.9 \\
\hline Prasung & 2 & 1 & 3 & 2 & 0 & 5 & 2 & 2 & 1 & 18 & 2.0 \\
\hline Sawohan & 3 & 1 & 3 & 2 & 4 & 5 & 3 & 4 & 1 & 26 & 2.9 \\
\hline Damarsi & 2 & 1 & 3 & 2 & 0 & 5 & 2 & 2 & 1 & 18 & 2.0 \\
\hline Pepe & 2 & 1 & 3 & 2 & 0 & 5 & 2 & 1 & 1 & 17 & 1.9 \\
\hline $\begin{array}{l}\text { Kalanganyar } \\
\text { Tambak }\end{array}$ & 4 & 4 & 3 & 2 & 3 & 5 & 4 & 3 & 1 & 29 & 3.2 \\
\hline $\begin{array}{l}\text { cemandi } \\
\text { Segoro }\end{array}$ & 2 & 1 & 3 & 2 & 4 & 5 & 2 & 4 & 1 & 24 & 2.7 \\
\hline $\begin{array}{l}\text { tambak } \\
\text { Banjar }\end{array}$ & 2 & 4 & 3 & 2 & 4 & 5 & 2 & 4 & 1 & 27 & 3.0 \\
\hline kemuning & 2 & 1 & 3 & 2 & 4 & 5 & 2 & 2 & 1 & 22 & 2.4 \\
\hline
\end{tabular}




\begin{tabular}{lccccccccccc}
\hline \multicolumn{1}{c}{ Villages } & Area & $\begin{array}{c}\text { Disaster } \\
\text { history }\end{array}$ & Elev. & Rainfall & $\begin{array}{c}\text { Mangrove } \\
\text { area }\end{array}$ & EWS & $\begin{array}{c}\text { Fishpond } \\
\text { area }\end{array}$ & $\begin{array}{c}\text { Fishpond } \\
\text { near the } \\
\text { river }\end{array}$ & $\begin{array}{c}\text { Water } \\
\text { supply }\end{array}$ & Tot & $\begin{array}{c}\text { Average } \\
\text { (Total/9) }\end{array}$ \\
\hline $\begin{array}{l}\text { Tambakoso } \\
\text { Kedung }\end{array}$ & 2 & 1 & 2 & 1 & 5 & 5 & 1 & 3 & 1 & 21 & 2.3 \\
$\begin{array}{l}\text { peluk } \\
\text { Plumbon }\end{array}$ & 2 & 1 & 3 & 4 & 4 & 5 & 3 & 3 & 1 & 26 & 2.9 \\
Kupang & 2 & 1 & 3 & 4 & 4 & 5 & 2 & 2 & 1 & 24 & 2.7 \\
Tambak & 4 & 4 & 5 & 1 & 2 & 5 & 3 & 5 & 1 & 30 & 3.3 \\
kalisogo & 3 & 4 & 5 & 1 & 4 & 5 & 3 & 3 & 1 & 29 & 3.2 \\
Permisan & 2 & 4 & 5 & 1 & 5 & 5 & 3 & 2 & 1 & 28 & 3.1 \\
Banjarasri & 1 & 1 & 3 & 1 & 0 & 5 & 2 & 2 & 1 & 16 & 1.8 \\
Banjarpanji & 2 & 1 & 3 & 1 & 0 & 5 & 2 & 2 & 1 & 17 & 1.9 \\
\hline
\end{tabular}

Source: Secondary data obtained.

The results of the analysis of physical coastal vulnerability maps of Sidoarjo Distric described in figure 4.

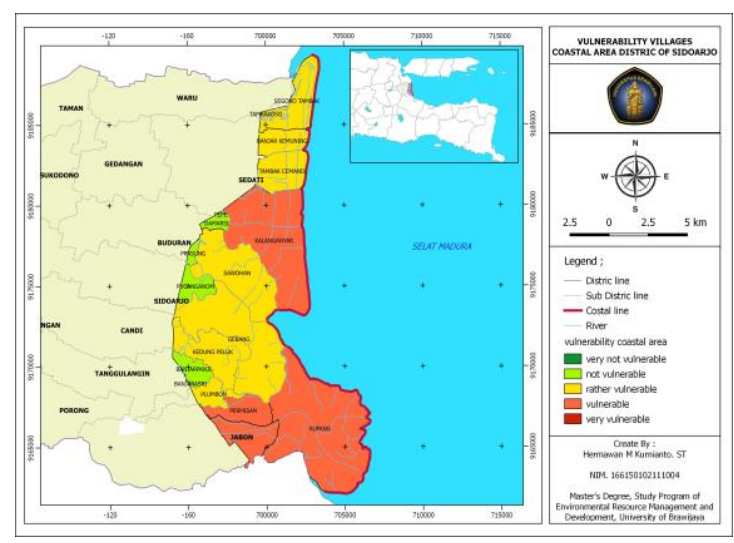

Figure 4. The Result of Physical Spatial map of the vulnerability coastal areas in Sidoarjo Distric.

\section{CONCLUSION}

Based on the results of the analysis, there have been identified 4 villages with very high physical vulnerability, among them Kalanganyar Village, Kupang, Tambak Kalisogo and Permisan Village.

The analysis of this research using 9 indicators of research due to data acquisition limitations in each agency and the limitations of data that can be compared to the village boundary, it is expected later in the day more and more indicators of parameters are compared so that obtained the maximum results, especially related to how far the intrusion sea water that has occurred in the coastal area of Sidoarjo Distric.

\section{ACKNOWLEDGEMENT}

USAID and local government og Indonesia

\section{REFERENCES}

[1]. Sakuntaladewi, Niken., Sylviani. 2014. Vulnerability And Efforts Of Coastal People's Adaptation To Climate Change. Center for Research and Development of Climate Change and Policy.

[2]. Samuel S., Mamauag, Porfirio M., Alino, Renmar Jun S., Martinez, Richard N., Muallil, Maria Victoria A., Emerlinda C, Dizon., Rollan C, Geronimo., Fleurdeliz M, Panga A,B., Reniel B, Cabral., 2013. A Framework For Vulnerability Assessment Of Coastal Fisheries Ecosystems To Climate Change Tool For Understanding Resilience of Fisheries (VA-TURF). Elsevier. Fisheries Research. Page. $381-388$.

[3]. BNPB. 2010. Socioeconomic Vulnerability Index Map In Indonesia. Jakarta

[4]. BNPB. 2013. Socioeconomic Vulnerability Index Map In Indonesia. Jakarta

[5]. Head of Sidoarjo Distric. 2011. Regional Regulation of Sidoarjo Regency No. 5 of 2011. Protection and Supervision of Coastal Areas and Small Island. Distric of Sidoarjo

[6]. BPBD Distric of Sidoarjo. 2017. Disaster Recapitulation of Sidoarjo Regency. Sidoarjo

[7]. Wibowo, Totok Wahyu., Putri, Erisa Ayu Waspadi., Loekman, Hanandy Yanuar. 2015. Evaluation Multi Criteria For Future Mapping of Vulnerability To Tsunami Hazard In Coastal Distric Bantul. Faculty of Geography Gadjah Mada University. Yogyakarta

[8]. Governor of East Java. 2012. Regional Regulation of East Java Province No. 6 of 2012. Management and Plan of Zoning of Coastal Area and Small Island of 2012-2032. East Java 
[9]. Governor of East Java. 2012. Explanation of Regional Regulation of East Java Province No. 6 of 2012. Management and Plan of Zoning of Coastal Area and Small Island of 2012-2032. East Java

[10]. J.E. Cinner., T.R. McClanahan., N.A.J. Graham., T.M. Daw., J. Maina., S.M. Stead., A. Wamukota., K. Brown., O. Bodin. 2011. Vulnerability Of Coastal Communities To Key Impacts Of Climate Change On Coral Reef Fisheries. ELSEVIER Global Environmental Change. JGEC-952; No. of Pages 9.

[11]. Central Bureau of Statistics. 2014. Potential Village Data (PODES). East Java

[12]. Central Bureau of Statistics of Sidoarjo Distric. 2016. "Kecamatan Dalam Angka". Sidoarjo

[13]. Central Bureau of Statistics of Sidoarjo Distric. 2016. "Kabupaten Sidoarjo Dalam Angka". Sidoarjo

[14]. BPBD Distric of Sidoarjo. 2014. Preparation of Disaster Management Planning in Sidoarjo Regency. Sidoarjo

[15]. Agustin, Shinta., Syamsidik., Fatimah, Eldina. 2016. Assesment Of The Index Of Physical Vulnerability The Coastal Area Of West Beach. South Aceh. Faculty of Engineering, Master of Civil Engineering Postgraduate Program Syiah Kuala University Banda Aceh. Aceh. Page. 71-80 